\author{
Arkadiy Bessarabov ${ }^{1}$, Tatyana Zakolodina ${ }^{1}$, Alexey Alyakin ${ }^{1}$ and \\ Gennady Zaikov ${ }^{2}$
}

\title{
THE SYSTEM ANALYSIS OF MARKETING RESEARCHES OF PHOSPHORIC INDUSTRY WASTE UTILIZATION BASED ON CALS CON CEPT
}

\author{
${ }^{1}$ State Scientific-Research Institute of Chemical Reagents and High Purity Chemical Substances \\ (IREA), 3 Bogorodsky Val, 107076 M oscow, Russia; bessarabov@irea.org.ru \\ ${ }^{2}$ Institute of Biochemical Physics, Russian Academy of sciences, 4 Kosygin str., 117334 M oscow, Russia \\ Received: August 26, 2008
}

(C) Bessarabov A., Zakolodina T., Alyakin A., Zaikov G., 2009

\begin{abstract}
A standard information CALS-system module of marketing research of a phosphoric industry waste utilization of large-capacity productions has been developed. The marketing research has been structured in the following categories: analysis of the raw material and processing market; analysis of waste processing technologies; analysis of the waste utilization products markets.
\end{abstract}

Keywords: system analysis, marketing, CALStechnologies, waste utilization, phosphoric industry, phosphoric sludge, phosphoric plaster, phosphoric slag

\section{Introduction}

Prediction of the competitiveness at an initial stage of development is an extremely complex and expensive task. Application of information CALS-technologies (Continuous Acquisition and Life cycle Support continuous information support of the product life cycle) allows to considerably facilitate this task [1]. A complex of uniform information models, standardization of access ways to the information and its correct interpretation under the international standards form the basis of CALS concept (Fig. 1). Thus, uniform ways of the development process control and interactions of all its participants are provided. The task of CALS is the conversion of product life cycle (LC) to a highly automated process by re-structuring (reengineering) of the business processes included into it. In the development of perspective chemical productions it is shown, that CALS-technologies and the main CALSstandard ISO 10303 STEP offer a way of solution of a problem of electronic representation of all LC stages: marketing, design, production, maintenance, and sales.

Implementation of CALS-technologies in the chemical industry implies introduction of modern resources of quality and competitiveness of technology production support that is the main condition of reaching sustainable development of a company. Another factor of similar importance when developing competitive production is marketing research. With the appearance and strengthening of marketing as the basis of market activity, market studies have been included in its framework and become its integral constituent. Without marketing it is impossible to determine the value of expenses for the technology development, experimental researches, equipment production, etc. [2]. Despite a number of publications dedicated to the application of CALS-technologies at «Design» and «Production» stages $[3,4]$, the application of CALS concept at the «Marketing» stage is practically not covered at all [5].

Purpose of our work is the development of the standard information CALS-system of marketing research of a phosphoric industry waste utilization of large-capacity productions (Fig. 2).

\section{Results and Discussion}

The trend of application of waste utilization products by their processing is ever increasing. Storage and stacking of waste containing phosphorus is hazardous to the ecology. Therefore there is a necessity for processing the accumulated waste and creation of wasteless productions. The main processing problem is the requirement that the final products of utilization should be in demand at the market. In our research attention was paid to the main production waste of a phosphoric industry - phosphoric sludge, phosphoric plaster, and phosphoric slag [6]. This research covers the key parameters of the market: volumes, prices, forecasts, as well as detailed aspects of applied technologies of existing waste processing. The main components of activity and 


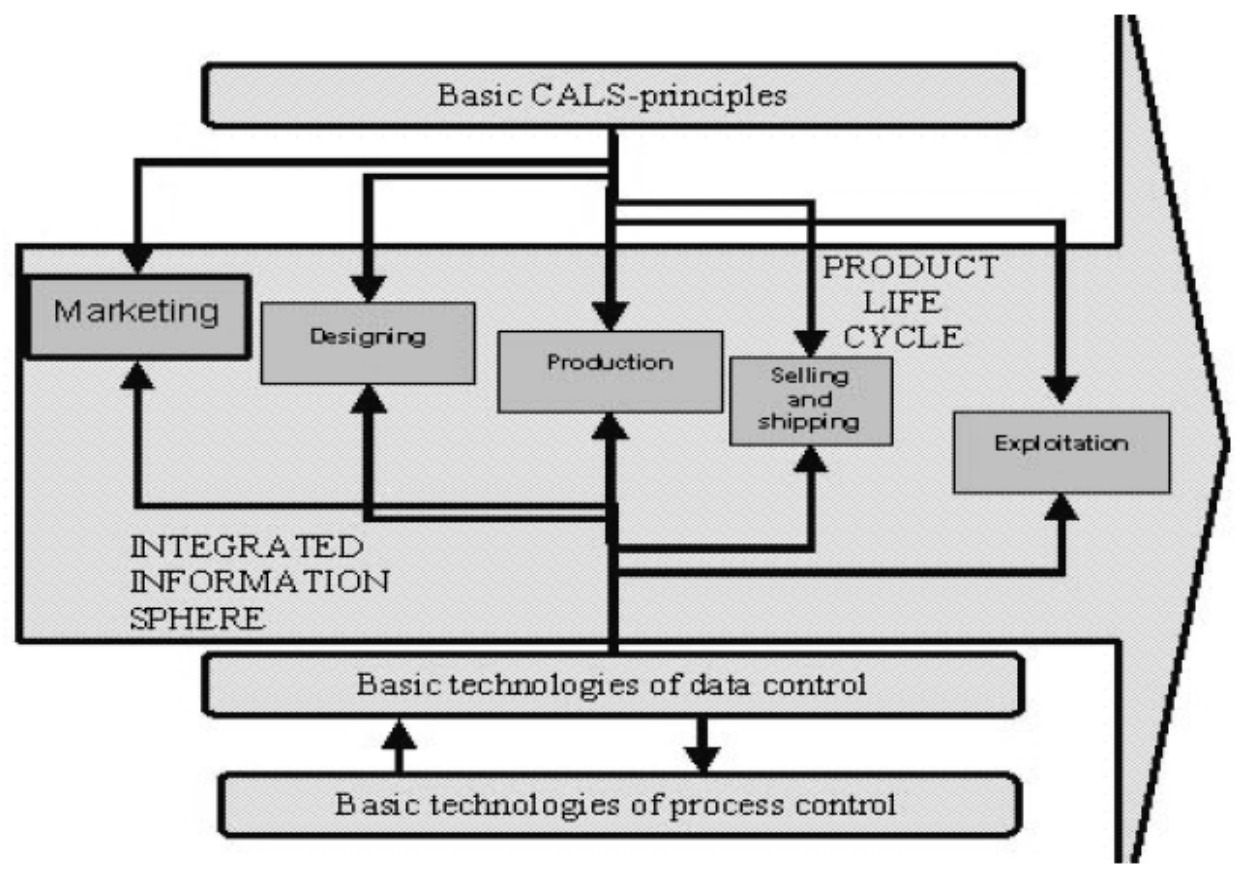

Fig. 1. Conceptual model of information CALS technologies

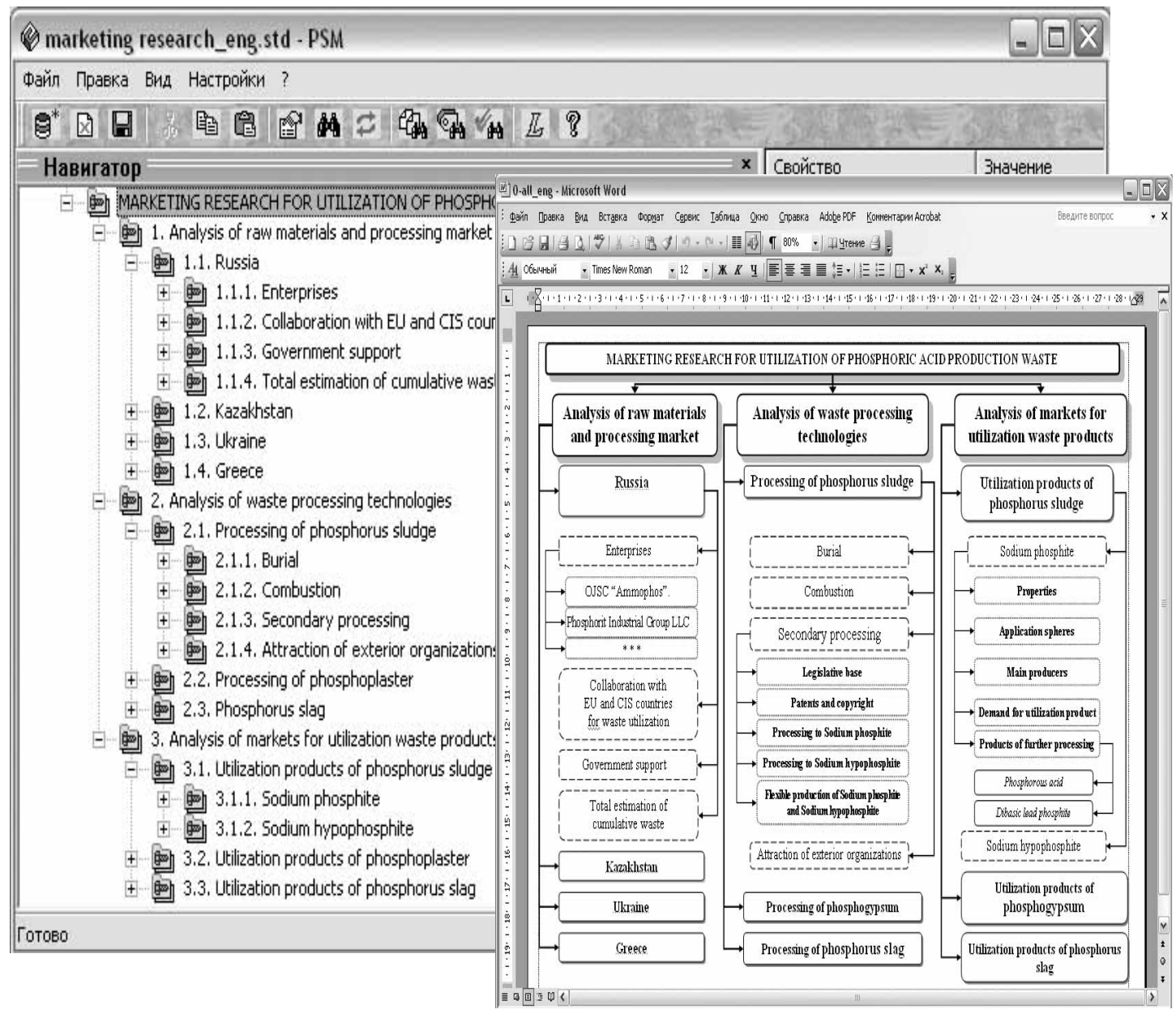

Fig. 2. The element of the CALS-project «Structure of marketing research of a phosphoric industry waste utilization of large-capacity productions» 


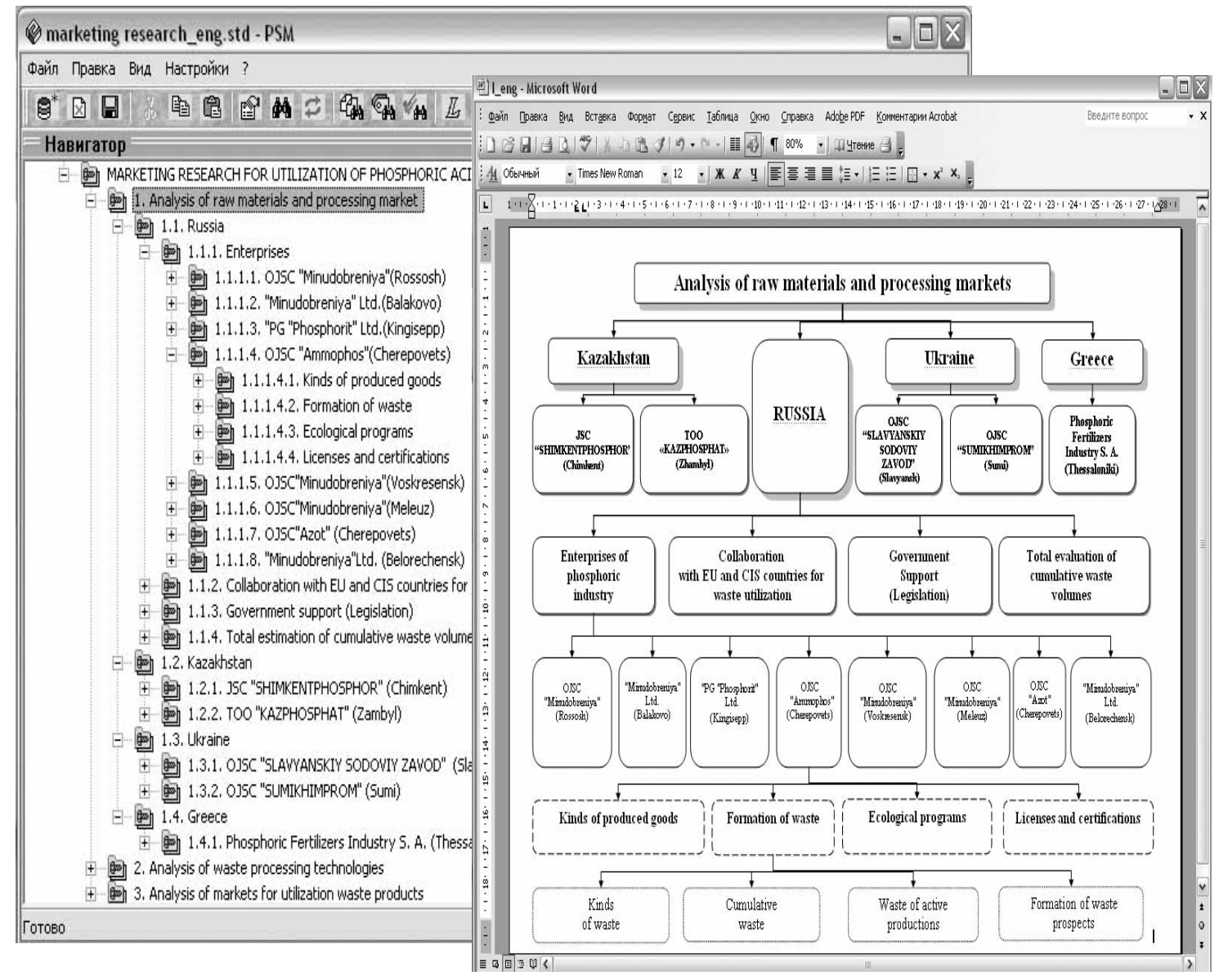

Fig. 3. The element of the CALS-project. The first category: «Analysis of the raw material and processing market»

development of the market in Russia, Kazakhstan, Ukraine, and Greece are analyzed while developing this module. The carried out marketing research has been structured in the following categories: analysis of the raw material and processing market; analysis of waste processing technologies; analysis of the markets of waste utilization products. All the above categories have been included in the developed CALS-project (module) (Fig. 2).

In the first category «Analysis of the raw material and processing market» (Fig. 3) for each of the countries considered (Russia, Kazakhstan, Ukraine, and Greece) the following four main subcategories have been brought: producers of the substances containing phosphorus (for example, in Russia); total waste accumulated within a country; existing government support enterprises producing phosphorous containing products; cooperation with other countries. In the «enterprises» subcategory the following leading enterprises of the phosphoric industry of Russia are brought: OJSC “Ammophos" (Cherepovets), "PG "Phosphorit Ltd." (Kingisepp), "Minudobreniya Ltd." (Balakovo), "Minudobreniya Ltd." (Belorechensk), OJSC "Minudobreniya" (Voskresensk), OJSC "Minudobreniya"
(Meleuz), OJSC “Minudobreniya” (Rossosh), OJSC "Azot" (Cherepovets), etc.

For each enterprise, the following information components are considered: sorts of the product manufactured; derivation of waste (sorts of the waste, accumulated waste, waste of acting productions and prospects of the new waste derivation); environmental programs of enterprise; licenses and certificates available at the given enterprise (Fig. 4).

In the category «Analysis of the raw material and processing market» the information on the governmental support for accumulated waste utilization of phosphoric industry enterprises, including general estimation of the accumulated waste on the territory of the above mentioned countries (starting from 2008) is given. In the last subcategory of the given section, the following information is accumulated: international cooperation between the countries considered in the CALS-project, teamwork and projects in the field of improvement of the phosphoric acid production technologies, existing methods of waste utilization and creation of joint ventures of the phosphoric industry. 


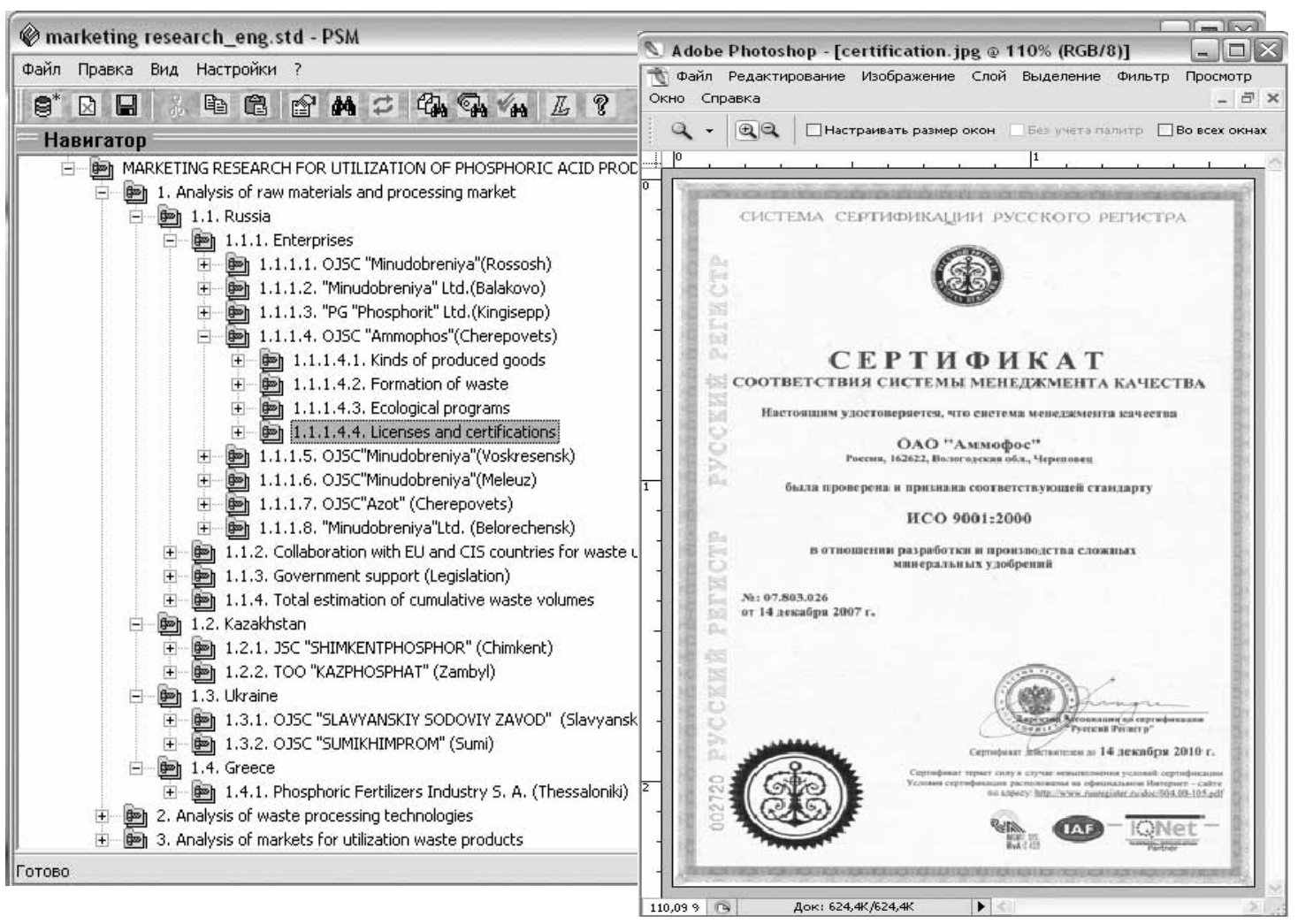

Fig. 4. The element of the CALS-project (module). The first category: «Analysis of the raw material ... ». Subcategories: Russia - Ammophos (Cherepovets) - certificates and licenses

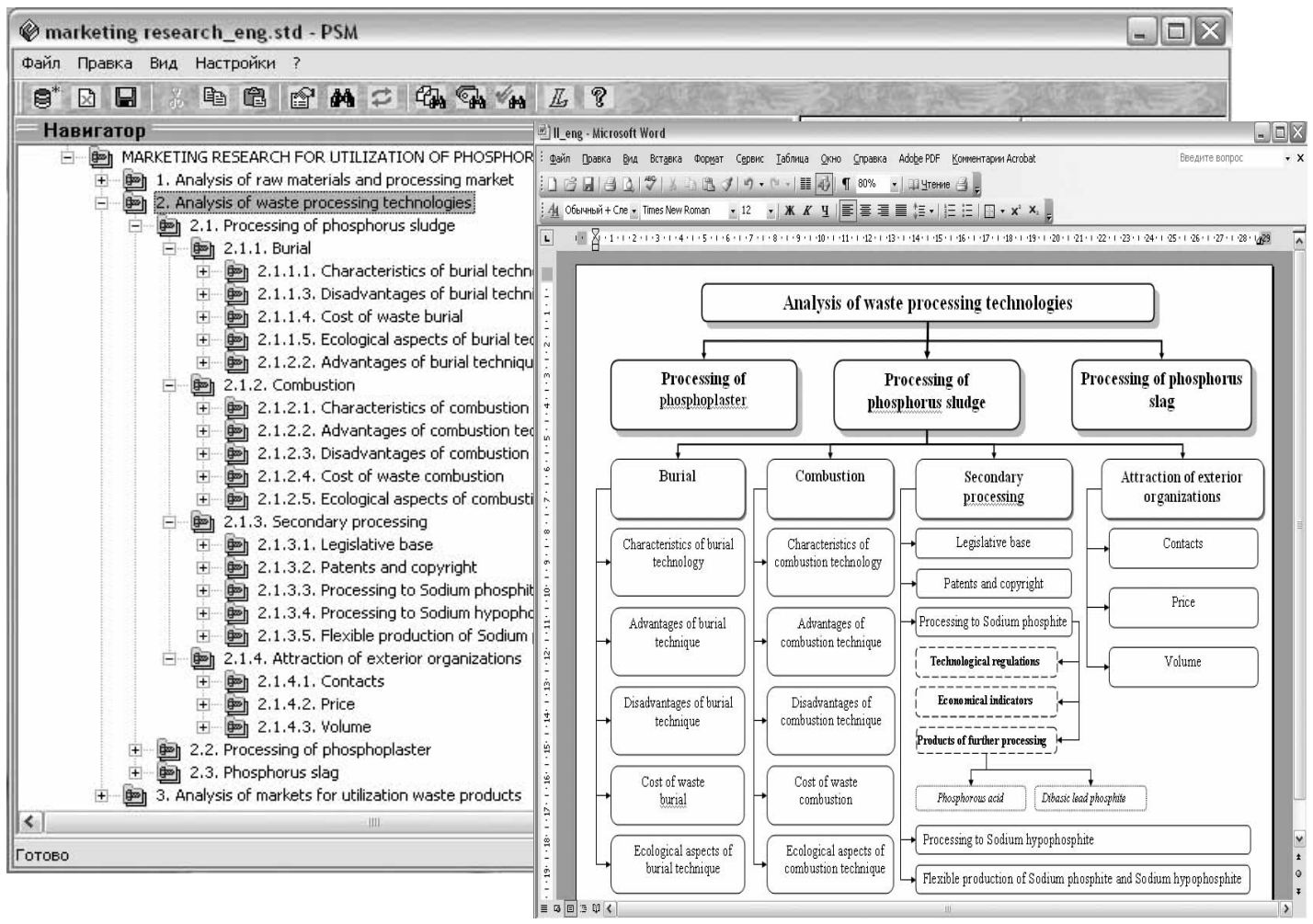

Fig. 5. The element of the CALS-project (module). The second category of the top level: «Analysis of waste utilization technologies» 
For the categories «Analysis of waste processing technologies» the data on the applied technologies of phosphoric sludge, phosphoric plaster, and phosphoric slag processing are included. Subcategory «Phosphoric sludge processing» contains four sorts of utilization: burial, combustion, and secondary processing as well as the list of companies rendering services in the sphere of utilization are given. Information for each utilization technology contains: characteristics of technology; advantages and disadvantages of technology; cost and ecological aspects (Fig. 5).

Within the limits of the second category of marketing model we developed the technology of secondary processing of phosphoric sludge waste to the sodium hypophosphite and phosphite [6]. Further analysis of two productions (sodium hypophosphite and phosphite) shows that they meet to two features of flexible chemical and technological systems, that is, they have technological and chemical similarity [7]. This enables to carry out synthesis of the flexible biproduct flowsheet. Such a flowsheet has been imported to the CALS-project (Fig. 6 ), in the category «flexible production of sodium hypophosphite and phosphite». The optimal flowsheet developed includes 23 process units: 9 combined units in which operations are carried out in terms of production of sodium phosphite as well as hypophosphite (solid line); 3 units only for production of sodium phosphite (dot line);
11 units only for production of sodium hypophosphite (dashed line). For transition from the one product to another 2 flexible sites of switching (FSS-1 and FSS-2) are included into the scheme. Flexible sites of switching allow enabling the release of target products at the minimum control actions. This reduces number of unit operators leading to lowering of the cost price.

Information about the products of utilization is brought to the third category of marketing research «Analysis of the markets of waste utilization products» (Fig. 7). Waste utilization products (phosphoric sludge, phosphoric plaster, and phosphoric slag) along with possible applications of utilization products were included into it.

For example, when recycling the phosphoric sludge one receives the following: sodium hypophosphite, applied as a component for an anticorrosive and decorative coating of various surfaces, that allows it to be the target commodity product which is in demand in the market; sodium phosphite - the restorer in inorganic synthesis and the reagent for synthesis of the dibasic lead phosphite in galvanics; the initial reagent for phosphorous acid obtaining; dibasic lead phosphite - an excellent thermostabilizer, working at high temperatures; phosphorous acid - the dibasic acid of average force applied as the restorer in chemical reactions.

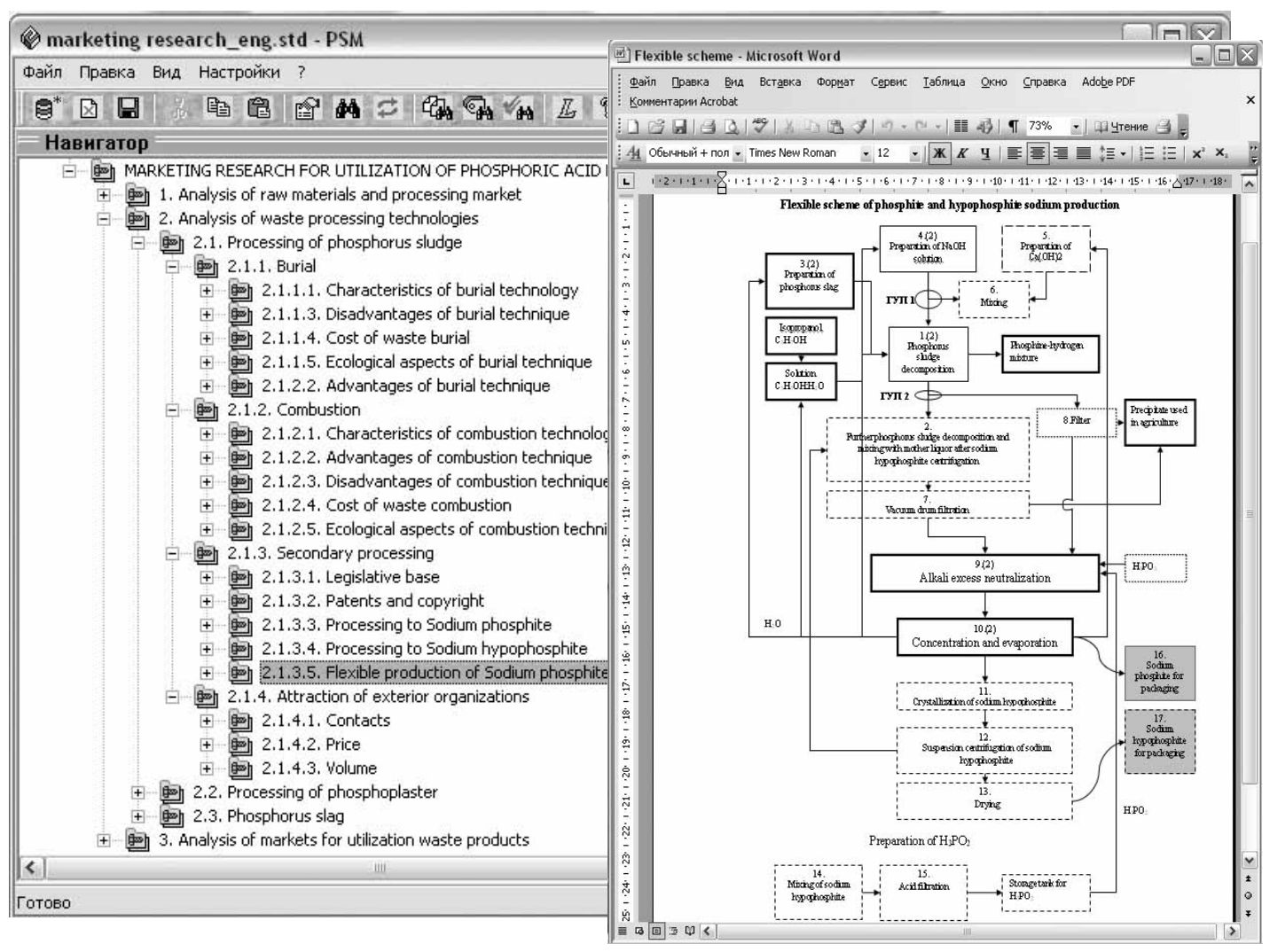

Fig. 6. The element of the CALS-project. The second category «Analysis of technologies ...»: phosphoric sludge processing - secondary processing - flexible production 


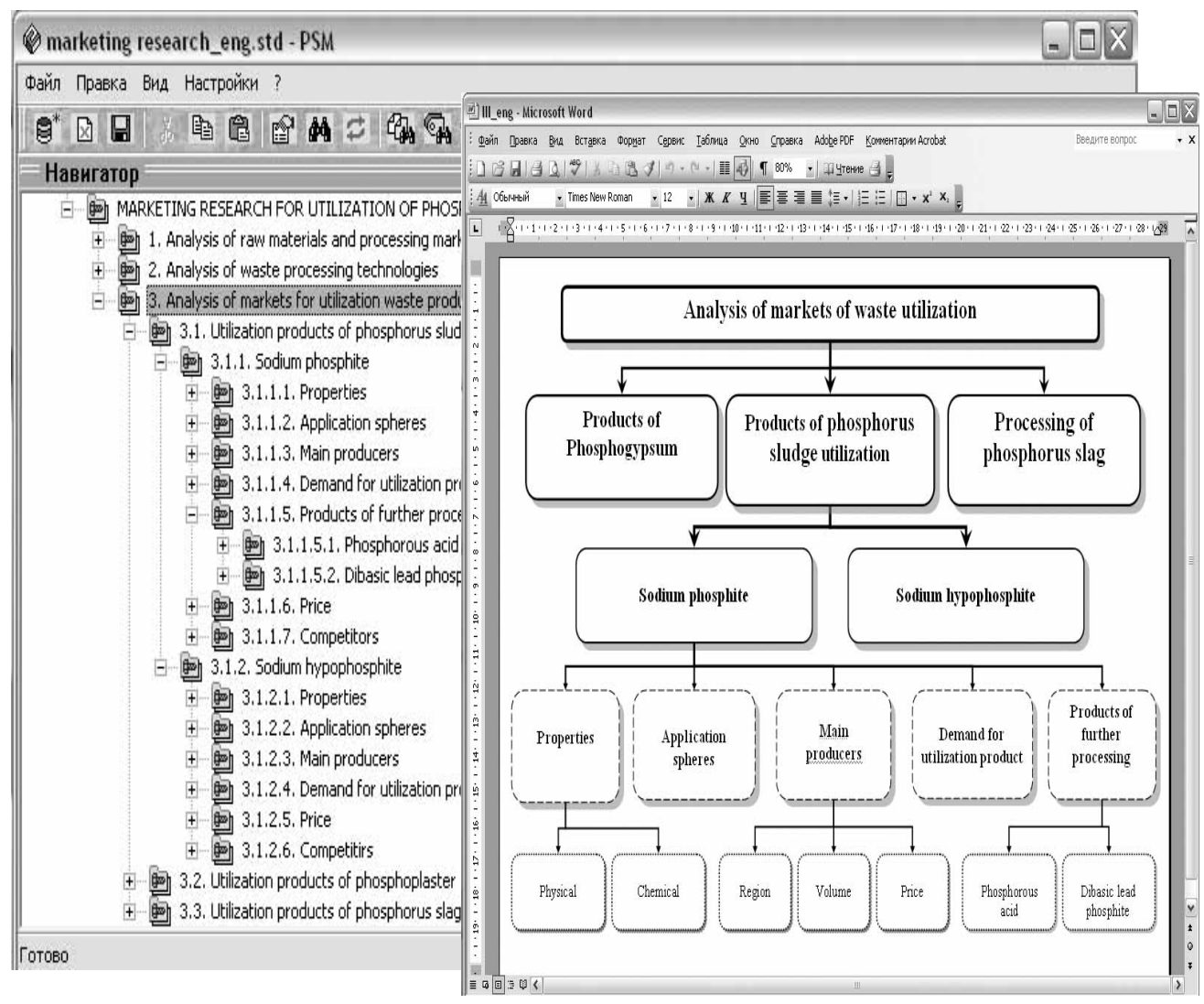

Fig. 7. The element of the CALS-project. The third top level category: «Analysis of the markets of waste utilization products»

\section{Conclusions}

Simplicity and efficiency of the user access to the available information at application of CALS-standards (ISO-10303 STEP) enables to expand qualitatively the commodity markets of products and technologies, as well as to capture a greater share of the market by application of the automated workstation. All the above mentioned will promote an active implementation of marketing latest researches in the field of practical computerization that will lead to greater competitiveness of waste utilization technologies of large-capacity chemical productions developed by us.

\section{Acknowledgements}

This work was partly supported by the European Commission in the context of the Project ECOPHOS (Contract No INCO-CT-2005-013359).

\section{References}

[1] Bessarabov A., Zhdanovich O., Yaroshenko A. and Zaikov G.: Oxidat. Commun., 2007, 30, 206.

[2] Kotler P. and Kellr K.: Marketing management. Prentice Hall, N.J. 2008.
[3] Bessarabov A., Zhdanovich O., Yaroshenko A. and Zaikov G.: J. Balkan Tribolog. Assoc., 2005, 11, 429.

[4] Bessarabov A., Ponomarenko A., Ivanov M. and Zaikov G.: Rus.J. Appl. Chem., 2007, 80, 13.

[5] Bessarabov A., Malyshev R. and Dem'yanyuk A.: Theor. Found. Chem. Eng., 2004, 38, 322.

[6] Bessarabov A., Koltsova E. and Ogorodnikova T.: $18^{\text {th }}$ Int. Congress of Chemical and Process Engineering CHISA 2008, Prague, Czech Republic, 2008, 1335.

[7] Bessarabov A., Puigjaner L., Koltsova E. and Ogorodnikova T.: $6^{\text {th }}$ Europ. Congress of Chemical Engineering, ECCE-6, Copenhagen, Denmark, 2007, 1, 445.

\section{СИСТЕМНИЙ АНАЛЗЗАРКЕТИНГОВИХ ДОСЛІДЖЕНЬ УТИЛІЗАЦІї ВІДХОДІВ ФОСФАТНОЇ ІНДУСТРІЇ НА ОСНОВІ САLS-ТЕХНОЛОГІЇ}

Анотація. Розроблено стандартний CALSсистемний інформаційний модуль маркетингових досліджень відходів великотоннажної фосфатної індустріі. Проведені маркетингові дослідження розділено на категорії: аналіз сировини іринкузбуту; аналіз технологічних прочесів переробки відходів; аналіз ринків утилізованих продуктів.

Ключові слова: системний аналіз, маркетинг, CALSтехнологія, утилізація відходів, фосфатна індустрія, фосфатний осад, фосфатний гіпс, фосфатний илак. 